\title{
Energy balance of pregnant vicuñas (Vicugna vicugna) in the Chilean High Andes
}

\author{
Cecilia Norambuena ${ }^{a, b^{*}}$, Karen Mussa ${ }^{a}$, Francisca Hernández ${ }^{a}$, \\ Jorge Alfaro ${ }^{a}$, Miriam Velasco ${ }^{a}$
}

\begin{abstract}
Energy unbalance may be the cause of low fertility rates found in vicuñas. The objective of this study was to estimate the temporal variation of the nutritional status in pregnant vicuñas from a herd kept under captivity in the Chilean High Andes. The hypothesis under study is that animals are able to maintain the energy balance during the dry season. Six pregnant vicuñas were examined in August, October and January (year 2015-2016). Reproductive status was estimated by ultrasonography and plasma progesterone concentration. Live weight (LW) and body condition score (BCS: 1-5 scale) were measured for each animal. A blood sample was taken to estimate the plasma concentrations of total protein (Biuret method), cholesterol (CHODPAP method), triglycerides (GPO-PAP method), $\beta$-hydroxybutyrate (enzymatic method) and non-esterified fatty acids (NEFA; enzymatic colorimetric method). Vicuña groups had similar LW, BCS, plus similar plasma concentrations of metabolites, total protein and progesterone. Females did not increase their LW during gestation and their BCS in January (2.9) was below the recommendations for late pregnancy in camelids (BCS 3.5). NEFA and $\beta$-hydroxybutyrate values were higher than those expected under nutritional energy balance signalling a lipolytic and ketogenic metabolic response, respectively. The absence of weight gain and the values of NEFA and $\beta$-hydroxybutyrate show that pregnant vicuñas suffer a negative energy balance during the dry season in the Chilean High Andes. This can cause abortion and contribute to low fertility rates of the herds. It is suggested to provide pregnant vicuñas with food supplements up to birthing, in years of severe drought.

Key words: vicuña, nutritional status, negative energy balance.
\end{abstract}

\section{INTRODUCTION}

The species of the Camelidae family are known for their ability to survive and reproduce in arid environments where other large herbivores cannot (Wensvoort et al 2001). The vicuña (Vicugna vicugna) is a wild mammal species, endemic to South America, and inhabits the Puna and High Andes biogeographic provinces of Peru, Bolivia, Argentina and Chile above 3,000 m.a.s.l.. This animal has been catalogued as "Least Concern" in the Red List of Threatened Species by the International Union for Conservation of Nature ${ }^{1}$. Low fertility rates have been described in wild vicuña populations in Chile, with a $38 \%$ birth rate recorded in vicuñas of the Nevado de Tres Cruces National Park (CONAF 2014) and a pregnancy rate of $59.7 \%$ in female vicuñas of the Lauca National Park (Urquieta and Rojas 1990).

The Chilean habitat for the species is characterised by a wet season (December to March) that concentrates $95 \%$ of the annual precipitation $(150-500 \mathrm{~mm})$ (Castellaro 2005, Castellaro et al 2004). This season is followed by a long period of severe drought, a dry season, with a high evaporation rate (April-November). It has been estimated that the forage supply of a highland bog

Accepted: 12.10 .2018 .

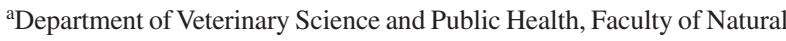
Resources, Catholic University of Temuco, Chile.

bNucleus of Research in Food Production, Faculty of Natural Resources, Catholic University of Temuco, Chile.

*Corresponding author: C Norambuena; Manuel Montt 056, Temuco, PC 4780000, Chile; mcnorambuena@uct.cl (bofedal) during the wet season can double that obtained during the dry season (Castellaro et al 2004). The lowest critical levels of forage quantity and quality extend from June to October (Raggi and Parraguez 2005), while the rise in environmental temperatures in spring and the arrival of rain during December promote plant growth (Castellaro 2005).

Castellaro (2005) estimated that the energy requirements of a pregnant-lactating vicuña $(3,649.6 \mathrm{MJ} / \mathrm{year})$ would be difficult to achieve between April and November, according to the forage supply and the energy content of the meadow. Vicuñas are generally sexually receptive during the wet season, and $95 \%$ of parturitions in Chile occur in February after a pregnancy of $347 \pm 7$ days (Raggi and Parraguez 2005). The foetal development of domestic camelids shows exponential growth around the seventh month of gestation (San Martin and Van Saun 2014). Therefore, the high nutritional demand for foetal growth coincides with the critical period of nutrient deficiency.

A poor nutritional state of the herds could partly explain low fertility indices, since it has been estimated that pregnancy rates are lower in light weight $(<37.5 \mathrm{~kg}$; $17.6 \%)$ rather than in medium weight (37.5-42.5 kg; 76.9\%) or heavy adult female vicuñas (> $42.5 \mathrm{~kg} ; 100 \%$; Ellmen 2004). In particular, the negative energy balance (NEB) did affect negatively the reproductive function in ruminant species and camelids (Patton et al 2007, Norambuena et al 2013). The objective of this study was to estimate the nutritional status of pregnant vicuñas kept in captivity in the Chilean High Andes. The hypothesis under the study is that pregnant vicuñas are able to maintain a nutritional energy balance during the altiplano dry season. 


\section{MATERIAL AND METHODS}

The study was carried out in a private farm of the Limani area (18 $23^{\prime}$ S, 69³4' W; 4385 m.a.s.1.), Parinacota Province. At the time of the study, the farm kept 49 vicuñas (13 males, 21 females and 15 unweaned offspring aged less than one year) in one paddock consisting of 40 ha of bofedal, in an extensive, grazing-based system. The animals were kept in one herd without distinction of sex or age, only being captured for shearing management every 2 years. The animal load was less than the carrying capacity determined in bofedales in the same area by Troncoso (1982). The study was authorised by the Agricultural and Livestock Service of the Chilean Government and the Bioethics Committee of the Universidad Católica de Temuco.

For the purpose of this study the vicuñas were captured in August 2015, October 2015 and January 2016. The herd was driven through a funnel, formed by fences into a corral, by five people on foot. Six pregnant females ( 5 to 7 years old) were chosen at random in the August sampling, and they were re-examined in October and January. Each vicuña was tied up and restrained in the sternal decubitus position during sampling which lasted about 30 min per animal. The animals were hooded to reduce stress and no sedation was used. The reproductive status was determined using rectal palpation and transrectal and transabdominal ultrasonography (7.5 mHz, Sonovet r3, Samsung Madison, USA) to identify the foetus or foetal membranes, and by plasma progesterone concentration. Live weight (LW) was estimated using a mechanical scale $( \pm 1 \mathrm{~kg})$, and body condition score (BCS) was assessed according to Van Saun (2009; scale 1-5). A blood sample was obtained (jugular venipuncture, $4 \mathrm{ml}$, heparinised tube) to estimate the plasma concentrations of total protein (Biuret method), cholesterol (CHODPAP method), triglycerides (GPO-PAP method), $\beta$-hydroxybutyrate (enzymatic method) and non-esterified fatty acids (NEFA; enzymatic colorimetric method). The samples were centrifuged immediately at $1,500 \mathrm{rpm}$ for
15 minutes. The plasma was transferred to the laboratory in a cooler with gel packs using land and air transportation $(18 \mathrm{~h})$, and stored at $-80^{\circ} \mathrm{C}$ until analysis in an automated clinical analyser (Metrolab 2300 Plus, Wiener Lab, Argentina). The plasma progesterone concentration was determined using a commercial solid-phase radioimmunoassay kit (Prog-RIA-CT, KIP 1458, Diasource, Belgium). The intra- and inter-assay coefficient of variation varied from $0.45 \%$ to $1.99 \%$ and $0.79 \%$ to $3.75 \%$ respectively; the limit of sensitivity was $0.53 \mathrm{ng} / \mathrm{ml}$.

The normal distribution (Shapiro-Wilks test) and the homoscedasticity (Levene's test) of the data were estimated. Comparisons were established between groups using Friedman's ANOVA test. If significant differences were detected $(P<0.05)$, Wilcoxon signed-rank test comparisons with Bonferroni adjustment for multiplicity were performed (SPSS Statistic Programme, V. 20).

\section{RESULTS AND DISCUSSION}

Vicuña groups had similar LW and BCS, plus similar plasma concentrations of metabolites, total protein and progesterone (table 1). Progesterone levels agreed with those found in pregnant domestic camelids (over $1 \mathrm{ng}$ / $\mathrm{ml}$; Bravo et al 1995) and they were slightly lower than those obtained in captive pregnant vicuñas $(2.8-6 \mathrm{ng} / \mathrm{ml}$; Raggi and Parraguez 2005).

The LW in all groups was similar to that reported for adult vicuñas (35-50 kg; Galaz 2005).

Pregnant females showed no increase in live weight between August and January, despite the fact that $70 \%$ of the newborn weight $(6 \mathrm{~kg})$ is reached during the last third of gestation in domestics camelids (Galaz 2005, San Martin and Van Saun 2014). The lack of weight gain might be due to the scarcity of water or nutrients, because a severe drought affected the Province during the year of performance of this study and the first rains fell after the January sampling. It must also be considered that the sample

Table 1. Animal characteristics and metabolic variables (Mean \pm SD) in pregnant vicuñas (Vicugna vicugna) maintained in captivity in the Chilean High Andes.

\begin{tabular}{lccc}
\hline Variables & August group & October group & January group \\
\hline Live weight (kg) & $48 \pm 4$ & $43 \pm 4$ & $45 \pm 5$ \\
Body condition score (1-5) & $2.8 \pm 0.3$ & $2.8 \pm 0.3$ & $2.9 \pm 0.2$ \\
Total Protein (g/l) & $73 \pm 8$ & $65 \pm 5$ & $64 \pm 11$ \\
Cholesterol (mmol/l) & $0.6 \pm 0.3$ & $0.7 \pm 0.2$ & $0.7 \pm 0.1$ \\
Triglycerides (mmol/l) & $0.3 \pm 0.1$ & $0.3 \pm 0.1$ & $0.3 \pm 0.1$ \\
NEFA (mmol/l) & $0.7 \pm 0.4$ & $0.7 \pm 0.5$ & $0.8 \pm 0.4$ \\
ß-hydroxybutyrate (mmol/l) & $0.17 \pm 0.22$ & $0.20 \pm 0.19$ & $0.13 \pm 0.25$ \\
Progesterone (ng/ml) & $1.3 \pm 0.2$ & $2.3 \pm 0.5$ & $1.6 \pm 0.6$ \\
\hline
\end{tabular}

NEFA is non-esterified fatty acid; different letters across rows indicates significant differences $(P<0.05)$. 
number was limited. The fat cover determined in January (BCS 2.9) was below the recommendations which state that domestic camelids should have a BCS of 3.5 during late pregnancy to ensure that reserves required to support lactation are available (Van Saun and Herdt 2014). Low BCS during pregnancy has been associated with lower lamb survival (Hinch and Brien 2014) and lower conception rate (Sejian et al 2009) in ewes.

Total plasma protein and cholesterol concentrations were similar to those obtained in vicuñas in captivity $(62 \pm 4 \mathrm{~g} / \mathrm{l} ; \mathrm{n}=36$ and $0.6 \pm 0.1 \mathrm{mmol} / \mathrm{l} ; \mathrm{n}=35$, respectively; De Vega et al 2015 ${ }^{\mathrm{a}, \mathrm{b}}$ ). There are no reference ranges of triglycerides, NEFA and $\beta$-hydroxybutyrate metabolites in vicuñas, although mean values for triglycerides were within the reference range for alpacas from European farms (0.1-0.5 mmol/l, $\mathrm{n}=88$; Foster et al 2009). A deficient energy intake increases blood concentrations of NEFA and $\beta$-hydroxybutyrate due to lipolysis and ketogenesis, respectively, in domestic camelids. Van Saun (2009) indicated that pregnant alpacas under conditions of nutritional energy balance have NEFA values of less than $0.4 \mathrm{mEq} / \mathrm{l}$ (equivalent to $0.4 \mathrm{mmol} / \mathrm{l}$ ), lower than the values found in this study. Also, the NEFA values of all groups were similar to those found in non-pregnant alpacas during the dry season in the Chilean altiplano (Norambuena et al 2018). Regarding $\beta$-hydroxybutyrate levels, fasting increased the $\beta$-hydroxybutyrate plasma concentration up to about 1 to $2 \mathrm{mg} / \mathrm{dl}$ (equivalent to 0.1 to $0.19 \mathrm{mmol} / \mathrm{l}$ ) in non-pregnant domestic camelids (Van Saun and Cebra 2014), which is similar to the ketone values obtained for all the groups in the present study. Low energy feeding during pregnancy increased the rate of abortion in ruminant species (Hussain et al 1996), a process that has been previously registered in a vicuña herd in Chile (13\% abortion rate; Ellmen 2004).

The absence of weight gain and the values of NEFA and $\beta$-hydroxybutyrate show that pregnant vicuñas suffer a NEB status during the dry season in the Chilean High Andes, which can cause abortion and contribute to low fertility rates of herds. The results of this study refute the hypothesis that animals are able to maintain a nutritional energy balance during the dry season, therefore, providing food supplements up to birthing to pregnant vicunas during years of severe drought is recommended.

\section{ACKNOWLEDGEMENTS}

The authors would like to thank Fondecyt Initiation Grant 11130206 (Dra. Norambuena), the Agricultural and Livestock Service of the Chilean Government, and Juan Flores, Cipriano Yusco and Gabino Yusco for their help during the field work.

\section{REFERENCES}

Bravo PW, Pezo D, Alarcón V. 1995. Evaluation of early reproductive performance in the postpartum alpaca by progesterone concentrations. Anim Reprod Sci 39, 71-77.
Castellaro G, Ullrich T, Wackwitz B, Raggi A. 2004. Botanical composition of alpaca (Lama pacos L.) and llama (Lama glama L.): diets in two seasons of the year on highland ranges of Parinacota province, Chile. Agric Téc 64, 353-363.

Castellaro G. 2005. Manejo nutritivo de la vicuña en condiciones de pastoreo. In: Galaz JL, González G (eds). Técnicas para el manejo productivo de la vicuña (Vicugna vicugna Molina, 1782) en Chile. Corporación Nacional Forestal, Santiago, Chile, Pp 221-246.

CONAF, Corporación Nacional Forestal. 2014. Informe XXXI Reunión Ordinaria Comisión Técnico-Administradora Convenio de la Vicuña. Ministerio de Agricultura. Santiago, Chile.

De Vega F, Abalos F, Carrizo E, Labarta F. 2015ª . Correlación biofisicoquímica de la colesteronemia con los perfiles metabólicos del sistema óseo en vicuñas de la localidad de Abra-Pampa, Jujui. In: Dayenoff P, Graselli A (eds.). Memorias del IX Congreso Latinoamericano de especialistas en Pequeños Rumiantes y Camélidos Sudamericanos. La Rioja, Argentina, Pp 164.

De Vega F, Abalos E, Sossa-Valdés F, Figueroa M, Puca Real C. 2015. Biofisicoquimica del proteinograma en vicuñas de la puna-Abra Pampa, Jujui. In: Dayenoff P, Graselli A (eds.). Memorias del IX Congreso Latinoamericano de especialistas en Pequeños Rumiantes y Camélidos Sudamericanos. La Rioja, Argentina, Pp 165.

Ellmen E. 2004. Efecto de la suplementación alimentaria estratégica sobre la eficiencia reproductiva en vicuñas mantenidas en semicautiverio. Memoria de Título, Facultad de Ciencias Veterinarias y Pecuarias, Universidad de Chile, Santiago, Chile.

Foster A, Bidewell C, Barnett J, Sayers R. 2009. Haematology and biochemistry in alpacas and llamas. In practice 31, 276-281.

Galaz JL. 2005. Antecedentes de la especie. In: Galaz JL, González G (eds). Técnicas de Manejo Productivo de la Vicuña (Vicugna vicugna Molina, 1782) en Chile. Corporación Nacional Forestal, Santiago, Chile, Pp 23-37.

Hinch GN, Brien F. 2014. Lamb survival in Australian flocks: a review. Anim Prod Sci 54, 656-666.

Hussain Q, Waldeland H, Havrevoll O, Eik LO, Andresen O, et al. 1996. Effect of type of roughage and energy level on reproductive performance of pregnant goats. Small Rumin Res 21, 97-103.

Norambuena MC, Silva M, Urra F, Ulloa-Leal C, Fernández A, et al. 2013. Effects of nutritional restriction on metabolic, endocrine, and ovarian function in llamas. Anim Reprod Sci 138, 252-260.

Norambuena MC, Hernández F, Alfaro J, Cárcamo G, Olavarría A, et al. 2018. Relationship between the nutritional state before the breeding period and the reproductive success in alpacas (Vicugna pacos) from the Chilean Puna. Austral J Vet Sci 50, 55-57.

Patton J, Kenny DA, McNamara S, Mee JF, O’Mara FP, et al. 2007. Relationship among milk production, energy balance, plasma analytes, and reproduction in Holstein-Frisian Cows. J Dairy Sci 90, 649-658.

Raggi LA, Parraguez VH. 2005. Manejo reproductivo de la vicuña. In: Galaz J, González G (eds). Técnicas de Manejo Productivo de la Vicuña (Vicugna Vicugna, Molina, 1782) en Chile. Corporación Nacional Forestal y Fundación para la Innovación, Santiago, Chile, Pp 209-221.

San Martin F, Van Saun R. 2014. Feeding management systems. In: Cebra C, Anderson DE, Tibary A, Van Saun RJ, Johnson LW (eds). Alpaca and Llama Care. Elsevier Inc., Philadelphia, PA, USA, Pp 91-100.

Sejian V, Maurya VP, Naqvi SM, Kumar D, Joshi A. 2009. Effect of induced body condition score differences on physiological response, productive and reproductive performance of Malpura ewes kept in a hot, semi-arid environment. J Anim Physiol Anim Nutr 94, 154-161.

Troncoso R. 1982. Evaluación de la capacidad de carga del Parque Nacional Lauca. Corporación Nacional Forestal I Región. Informe de Consultoría, $\mathrm{Pp} 222$.

Urquieta B, Rojas R. 1990. Studies on the reproductive physiology of the vicuna (Vicugna vicugna). In: Livestock reproduction in Latin America. International Atomic Energy Agency, Viena, Austria, Pp 407-428. 
Van Saun R. 2009. Nutritional requirements and assessing nutritional status in camelids. Vet Clin Food Anim 25, 265-279.

Van Saun R, Cebra C. 2014. Nutritional Diseases. In: Cebra C, Anderson DE, Tibary A, Van Saun RJ, Johnson LW (eds). Alpaca and Llama Care. Elsevier Inc., Philadelphia, PA, USA, Pp 124-139.
Van Saun R, Herdt T. 2014. Nutritional Assessment. In: Cebra C, Anderson DE, Tibary A, Van Saun RJ, Johnson LW (eds). Alpaca and Llama Care. Elsevier Inc., Philadelphia, PA, USA, Pp 100-123.

Wensvoort J, Kyle D, Orskov ER, Bourke DA. 2001. Biochemical adaptation of camelids during periods where feed is withheld. Rangifer 21, 45-48. 